\title{
Work context and employee behaviour as antecedents for intrapreneurship
}

\author{
J.P.C. Rigtering ${ }^{1}$ and U. Weitzel ${ }^{2}$
}

\begin{abstract}
Intrapreneurial employees and intrapreneurial projects are considered to be an important driver of innovation and strategic renewal within companies. While many studies addressed the top-down implementation of innovative projects, analyses of employee initiatives in promoting innovation within companies are scarce. This paper therefore takes a bottom-up approach and focuses on employee behaviour and how it can be stimulated towards intrapreneurship. We propose and test a two-step model where formal and informal work context affects employees' intrapreneurial behaviour, which then provides the basis for bottom-up initiated intrapreneurial projects. Our empirical data consist of questionnaire responses of 176 employees in six Dutch companies. The results of structural equation model estimations indicate that formal organisational factors (horizontal participation, resource availability) affect employees' intrapreneurial behaviour, but also highlight informal factors such as trust in the direct manager. We also find that innovativeness and personal initiative, but not risk taking, play a role for an effective translation of employees' behaviour into intrapreneurial projects.
\end{abstract}

Keywords: Intrapreneurship, Corporate Entrepreneurship, Entrepreneurial Orientation, Social Exchange Theory, Trust in Manager, Organisational Structure.

\footnotetext{
${ }^{1}$ Corresponding author: Utrecht University School of Economics, P.O. Box 80125, 3508 TC Utrecht, The Netherlands, +31-30-253 9800, J.P.C.Rigtering@uu.nl; and Windesheim University of Applied Sciences (The Netherlands)

${ }^{2}$ Radboud University Nijmegen, Institute for Management Research, P.O. Box 9108, 6500 HK Nijmegen, The Netherlands, +31-24-3616235, u.weitzel@ fm.ru.nl; and Utrecht University School of Economics (The Netherlands)
} 


\section{Introduction}

Due to rapid technological change, the ongoing economic/financial crisis and increasing international competition, the abilities of firms to change, improve and create new value have become ever more important. While some firms seem to have little problems in identifying and exploiting opportunities, others experience severe difficulties. These difficulties may harm firm performance, also in firms that appear to have ample resources available for opportunity seeking and opportunity exploitation (Gertz and Baptista 1996). Corporate entrepreneurship (CE), which is often also referred to as intrapreneurship, has, in this respect, become an increasingly important tool for practitioners to enhance a firm's performance and to foster innovation and opportunity exploitation within a firm.

Also in scholarly literature, $\mathrm{CE}$ has become an important research topic. $\mathrm{CE}$ has proven to increase a firms financial performance (see e.g. Rauch et al. 2009 for an overview), especially for firms that operate in hostile and dynamic/turbulent environments (Covin and Slevin 1989; Kraus et al. 2012; Wiklund and Shepherd 2005). Increased levels of financial performance are mainly due to strategic renewal within the organisation (Hayton and Kelley 2006; Zahra and Covin 1995), strategic repositioning of the organisation (Ireland et al. 2009), business venturing (Zahra 1995), increased levels of innovation (Zahra 1991) and increased flexibility (Ginsberg and Hay 1994).

CE is defined by Sharma and Chrisman $(1999$, p. 18) as: "the process whereby an individual or a group of individuals, in association with an existing organisation, create a new organisation or instigate renewal or innovation within that organisation". In the literature however, CE is usually studied as a top-down process of creating corporate change, renewal and flexibility through a managerial disposition towards innovative, proactive and risk taking behaviours (see e.g. Covin and Slevin 1989; Lumpkin and Dess 1996; Miller 1983; Rauch et al. 2009). Entrepreneurship within existing organisations can, however, be present at every level within the organisation (Kemelgor 2002; Monsen and Boss 2009) and the various manners in which entrepreneurial behaviour is exhibited across organisational levels can be considered as a main driver of the level of CE within a firm (Wales et al. 2011; Covin et al. 2006). As a result, research at different vertical organisational levels (top-management level, middle management level and employee level), is needed to understand how CE adds value to a company and why $\mathrm{CE}$ is more successful in some organisations (Wales et al. 2011). For the purpose of this study we therefore distinguish between entrepreneurial activities that are initiated top-down by the organisation (CE), and entrepreneurial activities that are pursued bottom-up by employees within an organisation (intrapreneurship). Although a distinction between topdown and bottom-up initiated entrepreneurial activities is essential in order to acknowledge that there are different frame conditions for entrepreneurial behaviour at (top) management level and at the employee level (see e.g. Dess et al. 2003), the terms CE and intrapreneurship are often used interchangeably. Sharma and Chrisman (1999), for instance, see intrapreneurship as a form of CE while other authors like Pinochet (1986), explicitly define intrapreneurs as employees that develop ideas and take hands on responsibility for the development of innovative new projects . 
An strong focus on CE does not automatically result in intrapreneurship (Burgelman 1983). Organisations, and large organisation in particular, are often not suitable environments for intrapreneurial behaviour (Sharma and Chrisman 1999) and disagreements between employer and employee are a major reason why many intrapreneurs leave their employer and start up an independent business (Klepper 2001). In a recent survey of the literature on intrapreneurship, Stam et al. (2012) identify six groups of important antecedents: dispositional traits, demography, cognitive abilities, job design, work context and broader environment. Of these antecedents, job design and work context are of particular interest for managers that seek to improve the level of CE within their organisation, as they can directly be influenced by organisational policies and managerial actions.

Many studies have shown that job design and work context are important antecedents of CE (e.g. Goodale et al. 2011; Knight 1987; Sun and Pan 2009). Other studies have specifically focused on job design and intrapreneurship (e.g. De Jong et al. 2011; D'Souza and Mulla 2011). Research on work context and intrapreneurship is, however, much more limited (Dess et al. 2003) and there is a lack of empirical work within this area. The pertinent literature on work context and intrapreneurship is either theoretical (e.g. Dess et al. 2003; Kanter 1988; Pinchot 1986), focuses on (middle) managers (e.g. Hornsby et al. 2002; Hornsby et al. 2009; Yang 2008), or on specific intrapreneurial behaviour by employees (e.g. Frese et al. 1997). Recently, there have been a couple of empirical studies (Axtell et al. 2000; Kirby 2006; Moriano et al. 2011; Wakkee et al. 2010; Zampetakis et al. 2009) that analyse intrapreneurial employees and the influence of the work context. However, the question how different organisational characteristics affect employees' intrapreneurial behaviour in relation to another remains largely unanswered. Empirical research has only begun to include a wider range of organisational characteristics as potential predictors of intrapreneurship (Axtell et al. 2000; Holt et al. 2007; Rutherford and Holt 2007; Zampetakis et al. 2009) and it is questionable to what extend results of $\mathrm{CE}$ research at the management level can be generalized to the employee level.

The contribution of this study is threefold. 1) Most empirical papers in the field of intrapreneurship research include a limited number of organisational level variables, without looking at more complex interactions between variables. Entrepreneurial behaviour within organisations is, however, the result of complex processes where environmental and organisational factors shape the opportunity structures in which people or groups function (Rutherford and Holt 2007). We therefore make a distinction between the formalized work context that can act as a catalyst or barrier to entrepreneurship (Zahra and Covin 1995; Burns 2008) and the informal work context of exchange relationships between the manager and employee. This combination of formal and informal work context has been recommended by Dess et al. (2003) and acknowledges that employees interpret formal organisational policies through the interactions with the direct manager. 2) While some papers focus on important innovative projects as the outcome of intrapreneurship (e.g. Kanter 1988; Knight 1987), others regard minor intrapreneurial behaviours displayed by employees as intrapreneurship (e.g. Axtell et al. 2000; Zampetakis et al. 2009). Although there are pro's and con's to both 
approaches, there are no empirical studies that combine these approaches and provide a more detailed empirical model. Within the present study, we develop a theoretical model (referred to as the two-step model of intrapreneurship) that predicts how intrapreneurship is stimulated within organisations and provide a simultaneous analysis of intrapreneurial behaviours displayed by employees, and the actual involvement in intrapreneurial projects that are of importance to the organisation as a whole. In doing so, we aim to present a more realistic analysis of the process of stimulating intrapreneurship within organisations. 3) In a more general context, this paper contributes to the growing body of literature on intrapreneurship. Most studies still focus on the corporate level and a of topdown implementation of entrepreneurial projects within organisations. Although this view dominates current literature, there is a growing consensus that research at different organisational levels is needed in order to improve our understanding of entrepreneurial processes within established organisations (Covin and Lumpkin 2011; Wales et al. 2011).

\section{Theoretical framework}

Before developing a two-step model of the intrapreneurship, we start with a description of the individual building blocks of the model (intrapreneurship, intrapreneurial behaviours, formal work context and informal work context). Within the model, a distinction is being made between employee level (intrapreneurship and intrapreneurial behaviours) and the organisational level (formal work context and informal work context). We start this section by defining intrapreneurship and the describing the type of intrapreneurial behaviours that are deemed essential for the intrapreneurial process. Next, we focus on the organisational level and describe the type of formal work context and the nature of informal exchange relationships (informal work context) that are needed to foster intrapreneurship within an organisation. We conclude the theoretical section of the paper with the development of the two-step model and hypotheses.

\subsection{Intrapreneurship}

Carrier (1996, p. 6) defines intrapreneurship as: "the introduction and implementation of a significant innovation for the firm by one or more employees working within an established organisation." This definition characterizes an intrapreneur, in line with Bosma et al. (2012), as an employee that takes the lead in introducing and implementing innovations. It also highlights, consistent with Pinchot (1986), the importance of idea implementation and innovation in intrapreneurship. The actual implementation, impact and level of innovation are considered to be of particular relevance to the definition of intrapreneurship, as intrapreneurship can only contribute to organisational renewal, business venturing, flexibility and profitability when projects move beyond the idea phase, are innovative and have significant impact within the organisation.

\subsection{Intrapreneurial behaviour}

Previous research on work context has typically focused on intrapreneurial behaviour and less on intrapreneurship (see Axtell et al. 2000; Frese et al. 1997; Moriano et al. 2011; Wakkee et al. 2010; Zampetakis et al. 2009). Indeed, a focus on intrapreneurship alone runs the risk of being too narrow, as it only regards those employees as intrapreneurs, who are active in significant, self-initiated projects of organisational renewal. There is 
however a much broader set of employee behaviour that can be regarded as intrapreneurial and therefore as a source for observed intrapreneurship.

CE research at firm level usually conceptualizes CE as a set of innovative, proactive and risk taking behaviour (see e.g. Covin and Slevin 1989; Rauch et al. 2009). These three dimensions are seen as essential for the corporate entrepreneurial process of recognizing opportunities and the reconfiguration of resources to exploit those opportunities. Also at employee level these three dimensions can also be considered key elements of intrapreneurial behaviour by employees. (i) Intrapreneurship requires behavioural elements as idea generation, opportunity recognition and idea implementation in order to come up with and implement radical as well as incremental innovations (West and Farr 1990). (ii) At the level of the employee, pro-activeness can also be described as, and extended to, the concept of personal initiative. Personal initiative is a self-starting persistent orientation towards shaping environmental conditions (Frese et al. 1997). Since intrapreneurs have to persevere in spite of obstacles, personal initiative seems to be a useful extension of pro-activeness in the intrapreneurial context. Only an intrapreneur who takes initiative, shows persistence, and who is able to find support within an organisation, is able to overcome organisational hurdles. (iii) When intrapreneurs challenge the status quo within organisations or behave in a proactive manner, they are likely to go beyond standard job descriptions and/or try to sell issues that are seen as controversial within the institutional setting (Parker and Collins 2010). Intrapreneurs could even act without the permission of higher management (Vesper 1984) and Stevenson and Jarillo (1990) emphasize that the pursuit of opportunities is likely to go beyond current controlled resources and, therefore, always entails a certain level of risk.

\subsection{Formal work context}

At the organisational level, the organisational structure of an organisation is often mentioned as an important antecedents of intrapreneurship (Hayton 2005; Hornsby et al. 1999; Kanter 1985; Kanter 1988). According to Mintzberg (1993) the design of individual positions within an organisational structure is characterized by two parameters: task specialization and formalization. Task specialization can be subdivided into horizontal participation, the extent to which work activities are highly specialized, and vertical participation, the extent to which responsibilities are marked out. Formalization is the extent to which organisations try to control and steer the behaviour of their employees through e.g. formal job descriptions, (work) procedures and rules (Mintzberg 1993). Organisations with high levels of formalization and high task specialization can be characterized as mechanistic organisational structures, while low levels of formalization and task specialization are typically related to organic and flexible organisational structures (Alexander and Randolph 1985).

Next to the organisational structure, the resources available for intrapreneurship are also considered as an important antecedent (Day 1994; Hornsby et al. 1993; Hornsby et al. 1999; Marvel et al. 2007). For the development of intrapreneurial projects, both time (Knight 1987) and money (Menzel et al. 2007) is needed. Although some authors consider time as a more crucial element to spur innovation and intrapreneurship within a 
company (e.g. Knight 1987), financial resources have proven to be very important when it comes to the implementation of ideas (Hornsby et al. 2002).

\subsection{Informal exchanges at the workplace}

The nature of informal exchanges processes within organisations is best described by social exchange theory (Blau 1967; Emerson 1976). Social exchange processes are characterized by uncertain (future) benefits and an inability to (legally) force a second party to fulfil its obligations (Blau 1967). Social exchange therefore depends on trust and reciprocity within the exchange relationship as expectations about performance of a second party are often formulated a priori and related to outcome expectations as well as interpersonal treatment (Rousseau 1989). The use of social exchange within intrapreneurship research emphasizes that actions and decisions of individual employees should be seen in a relational context; in which the relationship between the manager, who acts on behave of the organisation, and the employee is of particular relevance. At the heart of this exchange relationship is the notion of trust. According to Gambetta (1988) trust implicitly means that we do not expect that another person will harm us directly or indirectly or will behave in a, for us, unfavourable manner. Given the element of risk associated with intrapreneurial actions, trust in the direct manager is an important condition for intrapreneurial behaviour (Dess et al. 2003).

\section{Development of a two-step model and hypotheses}

Previous research (Axtell et al. 2000; Hornsby et al. 1999; Zampetakis et al. 2009) has shown that organisational characteristics affect employees' intrapreneurial behaviour. Hence, work context can be seen as an important antecedent for intrapreneurial behaviour within the organisation. This intrapreneurial behaviour, in turn, is needed to initiate and implement intrapreneurial projects. Employees that exhibit intrapreneurial behaviour are, however, likely to bump into organisational inertia, bureaucracy, and other hurdles (Burgelman 1983; Chisholm 1987). Although overcoming organisational hurdles is considered to be an integrative part of the process of CE (see e.g. Hornsby et al. 2002), not every employee who displays intrapreneurial behaviours will eventually implement an intrapreneurial project as the risk associated with intrapreneurship (e.g. potential damage to career) can be substantial (Hayton 2005). Thus, even though an intrapreneurial project may bare high potential for the company as a whole, the decision to opt for intrapreneurship remains an individual and personal decision when intrapreneurship is not a standard part of the job description of the employee. Another reason why intrapreneurial behaviour does not necessarily translate into intrapreneurial projects may be a lack of intrapreneurial opportunities in a firm. As an extreme example, even if all employees clearly display intrapreneurial behaviour, a firms current business situation may not allow each of them, or even any of them, to find, take up, or lead a new project. Therefore, from a process perspective, intrapreneurship is likely to follow a certain sequence. Employees first have to develop ideas and identify opportunities (intrapreneurial behaviour) before they can initiate and take the lead in innovative projects (intrapreneurship). Accordingly, and as explained in more detail below, we propose a two-step model, in which we refer to the stimulation of intrapreneurial 
behaviour by the organisation as 'step one', and to the individual decision of the employee to be actively involved in an intrapreneurial project as 'step two'.

\subsection{First step of the model}

In line with previous research, we advocate the view that intrapreneurial behaviour, in step one of the model, requires an formal organisation that allows employees to think outside the box (Frese et al. 1996; Hisrich 1990; Kanter 1988; Menzel et al. 2007) and that supports the development of innovative ideas (Knight 1987). Such an organisation is usually charactarised by flexible (Menzel et al. 2007) and flat (Kuratko and Goldsby 2004; Hisrich 1990) organisational structures and by high levels of both communication and cross functional intergration in order to promote knowledge sharing and facilitate organisational learning (Hayton 2005). This suggests high levels of both horizontal participation (broadly defined jobs), vertical participation (a flat organisational structure) and a limited number of organisational procedures (low levels of formalization), in order to give employees control over their job and autonomy at the workplace (Ginsberg and Hay 1994; Menzel et al. 2007). Next to the design of individual positions within the organisation, it also suggest an organisational willingness to allocate sufficient recourses to employees that want to develop, test, and introduce products, services or other types of innovations within the organisation (Day 1994; Hornsby et al. 1999). This leads to the following three hypotheses: ${ }^{3}$

H1 Employees with a high level of horizontal and vertical participation, show more intrapreneurial behaviour.

H2 Employees that experience the organisational structure as highly formalized, display less intrapreneurial behaviour.

H3 Employees that have more resources available for innovative projects, show more intrapreneurial behaviour.

Next to the formal work context, trust in the manager can be seen as an important condition for intrapreneurship within an organisation. Although most authors agree that mutual trust smoothens relationships between organisational members, theoretical arguments that trust increases performance at the workplace are scarce (BijlsmaFrankema et al. 2008). One of the exceptions to this rule is Möllering (2005), who argues that interpersonal trust creates an us-reality in which the goals of the trustor are aligned with the trustee. He concludes that reciprocity in the exchange relationship creates shared goals between the employee and the manager and causes employees to move beyond standard role requirements by exhibiting extra-role behaviour. The importance of a trustful relationship between the direct manager and the employee has been frequently substantiated when it comes to promoting intrapreneurship (see e.g. Hayton 2005). Employees have to be able to trust managers that they will not harm their position within

\footnotetext{
${ }^{3}$ In all hypotheses the term 'intrapreneurial behaviour' refers to, as explained in the previous section, more innovative behaviour, more personal initiative, and more risk taking, compared to other employees.
} 
the company when they exhibit intrapreneurial behaviours. This leads to the following hypothesis:

H4 Employees that have trust in their direct manager, show more intrapreneurial behaviour.

Exchange relationships should not only be analysed in direct relation to intrapreneurial behaviours, but also in relation to the organisational work context (Dess et al. 2003). We put forth that trust in the direct manager acts as an important moderating variable and changes the way employees deal with existing organisational procedures. Although people tend to think in both formal and informal procedures within organisations, their perceptions of the outcome of an organisational decision or procedure largely depends on a combination of formal and personal interactions between people (Folger 1987). Too much formal organisational procedures is expected to cause employees to exhibit less intrapreneurial behaviours. When employees have a relationship with their manager that revolves around mutual trust, bureaucratic procedures and organisational inertia may be less of a hurdle as they will trust upon the support of their manager to overcome such hurdles. This proposition, which puts the middle manager at the hart of the process of stimulating intrapreneurship, is very much in line with CE literature in general. Authors like Kuratko et al. (2005) and Hornsby et al. (2002) provide strong support for the pivotal role of middle managers in not only indentifying and exploiting opportunities, but also in creating and endorsing an environment in which intrapreneurial behaviour can thrive. Based upon in depth interviews with 24 technical intrapreneurs and 20 human resource managers, Marvel et al. (2007) concluded that the interpersonal way employees are being managed is one of the most important conditions for continued motivation for intrapreneurship. This leads to the following hypothesis:

H5 The relationship between formalisation and intrapreneurial behaviour is moderated by trust in the manager. Employees that trust their manager are less restricted in their intrapreneurial behaviour by high levels of formalization.

\subsection{Second step of the model}

Employees may choose to introduce and take the lead in implementing significant innovations within an organisation (intrapreneurship) or may decide not to, as this is unlikely to be a part of a standard job description. Employees that implement such significant innovations, and who therefore choose to become an intrapreneur, need to be innovative and show initiative in order to come up with ideas, get organisational support and to push projects through red tape. This also implies a willingness to be exposed to risks, as employees are likely to invest personal time, put their reputation on the line and as personal benefits, even in the case of success, are uncertain (Folger 1993). The stronger the employees tendency towards intrapreneurial behaviours, the more likely they will culminate in an intrapreneurial project. This leads to the following hypothesis:

H6 Employees with a higher level of intrapreneurial behaviour are more likely to be intrapreneurs. 
Intrapreneurial behaviours may also affect the strategic and financial importance of intrapreneurial projects. Entrepreneurial activities' within existing organisations are associated with, but not limited to, new product/service development, strategic renewal, strategic repositioning and new entry (Covin and Slevin 1989; Hayton and Kelley 2006; Ireland et al. 2009; Lumpkin and Dess 1996). Regardless whether these activities are commissioned top-down (CE) or bottom-up (intrapreneurship), their importance within the organisation depends, amongst others, upon the level of innovation and the extent to which the activities are applicable within the specific organisational context. We therefore expect that an employee with a strong focus on innovation is more likely to initiate more important projects, while a focus on personal initiative and a willingness to accept personal risks helps an employee to find organisational support and to push such projects through red tape. This leads to the following hypothesis:

H7 Employees with a higher level of intrapreneurial behaviour are involved in more important intrapreneurial projects.

Figure 1 provides an overview of the theoretical model and all hypotheses, which will be tested empirically:

\section{< INSERT FIGURE 1 ABOUT HERE >}

\section{Method}

In order to test our hypotheses, we collect survey data from individual employees. This is in line with other recent intrapreneurship studies such as Moriano et al. (2011) and Zampetakis et al. (2009). Given our two step model, we primarily use structural equation modelling (SEM) to test our hypothesis. SEM allows us to evaluate our two step model as a whole and provides more reliable results than the use of two successive multiple regression models.

\subsection{Sample}

We collected our data in six different Dutch organisations. Three of the six organisations are for-profit, while the other three can be characterized as non-profit organisations. Four organisations fall under the European Commission (2003) definition of small and medium sized enterprises, in casu quo employing ten or more employees but less than 250 employees. Two organisations employ more than 250 employees and can be categorized as large organisations (see European Commission 2003). In our empirical analysis, we control for organisational size and for profit versus non-profit orientation (see below).

Within each organisation the same sampling procedure was applied. First, in colloquium with the company management, the sample size was determined. Both employees and team leaders/operational managers where included in the sample, since the development and implementation of corporate renewal is not considered to be a standard part of their job description. A number of steps were taken to increase the response rate, to ensure that respondents could respond openly to the questions, and that they felt safe in doing so. 
These steps include an email by the company management sent two weeks prior to the actual survey, in which the management expressed their support for our research and briefly explained its purpose. The online questionnaire itself included an email from the research team, which highlighted the anonymity and the importance of the responses. One-and-a-half to two weeks later, participants received a reminder to fill in the questionnaire. During the entire data collection period, an email address was available for questions by potential respondents. All survey questions where non-compulsory. The measures mentioned above are in line with recommendations by Dillman (1978) for increasing the response rate and reliability of questionnaire results. The response rates within the different organisations ranged from $30 \%$ to $66.67 \%$. An overview of all sample statistics can be found in Table 1 .

\section{< INSERT TABLE ONE ABOUT HERE >}

\subsection{Operationalization of measures}

All scales where taken from or based upon existing measures and translated from English to Dutch (if applicable). A back translation procedure was applied to ensure that all items were adequately translated. All items are, unless mentioned otherwise, measured on a 7Point Likert-type scale ranging from completely disagree to completely agree. All independent variables, as shown in Figure 1 and presented below, were computed as regression based factor scores. The questionnaire is available from the authors upon request.

\subsubsection{Intrapreneurship}

Consistent with the operationalisation of entrepreneurial employee behaviour in the Global Entrepreneurship Monitor (2012), intrapreneurship is measured as active involvement in the development of an self-initiated project of corporate renewal and taking the lead within this respective project. Respondents where first asked if they, during the last two years, had participated, alone or within a team, in a project with the purpose of creating renewal within the company (development of new products, services, organisational processes and/or strategies). If respondents had participated in such a project or were currently participating in such a project, they were asked to evaluate their role within this project (leading role, supporting role or both). Respondents that were identified as intrapreneurs (participate in an intrapreneurial project and taking the lead within this respective project), were also asked to evaluate both the strategic and financial importance of this project (measured on a five point Likert-type scale ranging from very small to very important).

\subsubsection{Intrapreneurial Behaviour}

The three different dimensions of intrapreneurial behaviour are measured by using three different measurement scales. For the level of innovative workplace behaviour a measurement scale developed by De Jong and Den Hartog (2010) is used. This measurement scale consists of ten items that reflect idea generation, exploitation, the championing of ideas and idea implementation. Personal initiative is measured through the personal initiative scale of Frese et al. (1997). This scale has been used in many other studies and has been proven to be very reliable. The level of employee risk taking was 
measured by three risk taking items developed by De Jong et al. (2011). These items measure both the risk taking propensity of the employee as well as the tendency for more bold (risky) actions within an organisation setting.

\subsubsection{Organisational structure}

The dimensions of organisational structure, horizontal participation, vertical participation and formalization, were measured by twelve questions based upon an instrument developed by Leifer and Huber (1977) and Alexander and Randolph (1985). This instrument has been used in many different organisational settings in the past and has been proven to be reliable.

\subsubsection{Resources available}

A scale developed by De Jong and Den Hartog (2005) is used to measure the level of resource availability in the organisation. This scale includes questions on the amount of both financial and non-financial (e.g. time) means available in the company to develop new ideas.

\subsubsection{Trust in manager}

The level of trust in the direct manager is measured with three items, adapted from Bijlsma-Frankema (2000) and Bijlsma and Van de Bunt (2003). The scale includes items on the level of trust in the personal and professional relationship between the manager and employee.

\subsubsection{Control variables}

We include gender (1=male), age (measured in number of years), and a dummy for the level of education ( $1=$ Bachelor degree or higher) in our structural models to control for demographic differences between individual respondents. We also add two control variables to correct for firm-level differences in work context, which are not due to organisational design or policies within the firm. Donaldson (1995), for example, points out that the complexity of the organisational structure and the level of bureaucracy usually increase as firms grow. We therefore added the dummy variable SME $(=1)$ to control for the less complex organisational structures and policies that may result from a smaller firm size. Further, non-profit organisations may be more constrained in the number of resources that they can allocate for innovative projects. We therefore also include a dummy for non-profit organisations $(=1)$ as a second firm level control variable.

\section{Data analysis}

\subsection{Factor analyses and reliability}

Before testing the hypothesized model, a confirmatory factor analysis (CFA) is used to assess the convergent and discriminatory validity of the independent variables. In order to

determine the level of model fit, the $\chi^{2}$ of the measurement model and the Root Mean Square Error of Approximation (RMSEA) are being used. The RMSEA is considered as the most reliable fit index when examining confirmatory factor models (Rigdon 1996). In line with Parker et al. (2003) a RMSEA value of .08 is considered to be a liberal measure of model fit and .05 an indication for very good model fit. 
The original CFA provides a mixed picture. The the $\chi^{2}$ test suggests that the model does not fit the data very well, while de RMSEA suggests good model fit $\left(\chi^{2}=208.161(125), p\right.$ $=<.001$, RMSEA .062). A closer examination of the measurement model revealed, however, that all items of the bureaucracy dimension vertical participation display, significant cross loadings on multiple factors (trust, horizontal participation and formalization). In order to improve the measurement model, vertical participation is removed, since it lacks discriminatory validity and cannot be considered as an independent variable within our structural model. The new CFA yields, given that the $\chi^{2}$ test is sensitive to the number of variables that are included in the analysis, an improved model fit $\left(\chi^{2}=90.607(59), \mathrm{p}=<.01\right.$, RMSEA .055) and all items load significantly $(\mathrm{p}=$ $<.001)$ on their hypothesized latent constructs. The latter can be considered as an indication for convergent validity (Byrne 2010).

The reliability of the different scales is estimated by a Cronbach's alpha test. A Cronbach's alpha above .70 is generally preferred, while a value above .80 is an indication for strong internal consistency (De Vaus 2002). Most scales in our study display reasonable levels to very good levels of reliability, ranging from .72 (level of formalization) to .90 (trust in supervisor and resource availability). The Cronbach's alpha of the horizontal participation scale (.67) and risk taking (.68) is slightly below .70. A value between .60 and .70 is, however, still acceptable for exploratory purposes (Hair et al. 2007). As removing items from these measurement scales has hardly any effect on the Cronbach's alpha, no items have been deleted.

\subsection{Statistical checks}

As the data for the present study has been collected at one point in time, the reported relationships can be the result of variance attributable to the measurement instrument instead of the relationships under study (also known as common method variance or method variance) (Podsakoff and Organ 1986; Podsakoff et al. 2003). A Harman's single factor test is used to test for the existence of common method variance. Common method variance is considered a major problem and threat to the validity of the results if one factor explains more than 50\% of the variance in the dataset (Podsakoff and Organ 1986). All items from all constructs under study where included in the analysis. The result of the Harman's single factor test shows that common method variance is not a concern; the single factor explained only $20.83 \%$ of the total variance.

\section{Results}

\subsection{Bivariate analysis and descriptive statistics}

Pearson correlations where used for an initial examination of the hypothesized relationships. All Pearson correlations and descriptive statistics for all variables under study are shown in Table 2.

The table shows that, in line with our expectations, none of the antecedents directly affect any of the intrapreneurship measures $(\mathrm{p}=>.10)$. This provides initial support for our two-step model of intrapreneurship. Of the three dimensions of intrapreneurial behaviour, 
innovative workplace behaviour $(\mathrm{r}=.29, \mathrm{p}=<.01)$ and personal initiative $(\mathrm{r}=.33, \mathrm{p}=<$ .01 ) are positively related to changes of participating in an intrapreneurship project. Risk taking is negatively associated with intrapreneurship, although this effect is not significant $(\mathrm{p}=>.10)$. Risk taking does affect the financial performance of intrapreneurial projects positively $(\mathrm{r}=.16, \mathrm{p}=<.10)$. Respondents that report higher levels of innovative workplace behaviour participate in both financially $(\mathrm{r}=.28, \mathrm{p}=<$ $.01)$ and strategically $(\mathrm{r}=.35, \mathrm{p}=<.01)$ more important projects. Personal initiative is only positively and significantly related to strategically more important intrapreneurial projects $(\mathrm{r}=.29, \mathrm{p}=<.01)$.

Trust in the direct manager and horizontal participation are important predictors of both innovative workplace behaviours $(\mathrm{r}=.18, \mathrm{p}=<.05$ and $\mathrm{r}=.25, \mathrm{p}=<.01$, respectively) and personal initiative at the workplace $(\mathrm{r}=.25, \mathrm{p}=<.01$ and $\mathrm{r}=.19, \mathrm{p}=<.05$, respectively). The level of formalization, in contrast to our expectations, positively affects innovative behaviour at the workplace $(\mathrm{r}=.16, \mathrm{p}=<.10)$, as well as personal initiative $(\mathrm{r}=.12, \mathrm{p}=>.10)$. The level of resources available to respondents does not affect innovative workplace behaviour or personal initiative. None of the antecedents are associated with risk taking behaviour $(\mathrm{p}=>.10)$.

\section{$<$ INSERT TABLE 2 ABOUT HERE >}

\subsection{Multivariate analysis}

The notion that the formal and informal work context does not directly affect the level of intrapreneurship within the firm, but only through employees' intrapreneurial behaviour, can be challenged by a direct model in which work context affects both intrapreneurial behaviour and intrapreneurship simultaneously. We therefore start with an assessment of our hypothesised two-step model. Using SEM (AMOS 18), we compare the model fit of our two-step model against a model in which both types of intrapreneurship are directly affected by the formal work context and trust in the direct supervisor. Next, we include the different control variables in the two-step model and focus on the structural relationships. Since SEM is unable to estimate the $\beta$ of a dependent dummy variable, we estimate the $B$ of the relationship between the dimensions of intrapreneurial behaviour and intrapreneurship by running a Bayesian analysis. In contrast to an maximumlikelihood estimation, a Bayesian estimation considers any unknown quantity as a random variable and therefore seeks to specify its probability distribution (Byrne 2010). The prior distribution (theoretical distribution of the parameters) is therefore combined with the empirically observed distribution by a process of random sampling to form the posterior distribution (Arbuckle 2007). The mean of this posterior distribution is commonly reported as the parameter estimate, while the standard deviation can be considered as the standard error. In AMOS, this process of random sampling is accomplished through the Markov Chain Monte Carlo algorithm (MCMC). For each analysis we simulated approximately 180,000 samples and report the $95 \%$ confidence interval of the $\beta$. The likelihood of the MCMC is assessed by comparing the parameter distribution of the first and last thirds of accumulated samples. If the distributions are close to identical, AMOS has successfully identified important features of the structural relationship (Byrne 2010). The difference between respondents that report low levels of 
trust in their manager and respondents that report high levels of trust in their manager are being analysed by splitting the sample into two groups (low trust in manager, high trust in manager). The significance of interaction effects is being tested by constraining the regression parameter to be equal in both groups and analysing the increase in $\chi^{2}$ in the measurement model.

Table 3 shows that the fit of the two-step model of intrapreneurship is, on average, significantly better than the direct model. Because of the absence of any significant correlations between the variables under study and risk taking, specifications for a model with risk taking do not result in a better fit. On the basis of the results of the innovative behaviour and personal initiative model, we therefore conclude that our two-step model is the more accurate empirical model.

\section{$<$ INSERT TABLE 3 ABOUT HERE >}

As shown in Table 4, horizontal participation and trust in the manager both affect innovative workplace behaviour positively $(\beta=.27, \mathrm{p}=<.01 ; \beta=.16, \mathrm{p}=<.05$, respectively). This also applies to the level of personal initiative $(\beta=.19, \mathrm{p}=<.05 ; \beta=$ $.24, \mathrm{p}=<.01$, respectively). This provides partial support for $\mathrm{H} 1$ and $\mathrm{H} 4$, as no significant relationship with risk taking behaviour has been found. The level of formalization within a company does not affect any of the intrapreneurial behaviours, leading to the rejection of $\mathrm{H} 2$. The level of resources available positively affects the amount of innovative workplace behaviour and personal initiative $(\beta=.21, \mathrm{p}=<.01 ; \beta=$ $.16, \mathrm{p}=<.05$, respectively), but does not affect the level of risk taking behaviour. This provides partial support for $\mathrm{H} 3$. We also find noticeable differences in employee risk taking between SMEs and large firms $(\beta=-.29, \mathrm{p}=<.10)$ and between non-profit and for-profit firms $(\beta=-.25, p=<.10)$. Both SMEs and non-profit firms seem to allow less room for risk taking behaviours by their employees.

\section{$<$ INSERT TABLE 4 ABOUT HERE >}

As shown in Figures 2, 3 and 4, AMOS was successful in identifying the important elements of the structural relationship and the reported $\beta$ 's in Table 4 can therefore be regarded as reliable. It is important to note that the size of the firm (large or SME) affects the chances that an employee is involved in an intrapreneurial project (see Table 4). The financial impact of intrapreneurial projects is, however, stronger in SMEs $(\beta=.31, p=<$ .10). Working in a not-for-profit organisation, reduces the chances of being involved in an intrapreneurial project (see Table 4). Employees that display innovative workplace behaviour and personal initiative are more likely to be intrapreneurs and are involved in more strategic and financial projects (see Table 4). Risk taking employees are, however, not more likely to be involved in intrapreneurial projects (the $\beta$ is very close to 0 and even slightly negative), and are only active in more financially important projects. H6 and $\mathrm{H} 7$ are therefore only partially supported.

< INSERT FIGURE 2 ABOUT HERE > 


\section{< INSERT FIGURE 3 ABOUT HERE > \\ $<$ INSERT FIGURE 4 ABOUT HERE >}

Table 5 reports the differences of the structural parameters between respondents that report low levels of trust in their manager versus respondents that report high levels of trust in their manager. Noticeable differences are found in the way formalization affects both innovative workplace behaviours and personal initiative. Formalization in the organisation has a negative effect (although this effect is not significant) on innovative workplace behaviour and personal initiative within the group with low trust in their manager. Formalization, however, positively affects innovative workplace behaviour when employees trust their manager $(B=.25, \mathrm{p}=<.01)$. This also applies to personal initiative $(\beta=.23, \mathrm{p}=<.10)$. The difference of the structural parameter was found to be significant in the model with innovativeness $\left(\Delta \chi^{2}=5.133(1), \mathrm{p}=<.05\right)$ but not in the personal initiative model, $\mathrm{H} 5$ is therefore partially supported.

\section{$<$ INSERT TABLE 5 ABOUT HERE >}

\section{Discussion}

The four main findings of this study are: (1) Intrapreneurship within organisations is not affected directly by the work context, but indirectly through innovative workplace behaviour and personal initiative by employees. (2) Formal organisational work context characteristics such as horizontal participation and the number of resources affect the level of innovative behaviours and personal initiative within an organisation, but not risk taking. (3) Trust in the direct manager plays an important role in the stimulation of innovative behaviours and personal initiative amongst employees. (4) Risk taking behaviour by employees is not related to the involvement in an intrapreneurial project.

Against the backdrop of large discrepancies between operational definitions of intrapreneurship, our two-step model of intrapreneurship offers a combination of approaches, by integrating concepts that only regard participation in important innovative projects as intrapreneurship with broader concepts of intrapreneurial behaviour. In doing so, we offer a more detailed model of the intrapreneurial process that also highlights the complexity of facilitating intrapreneurship within an organisation. Although the predictive validity of innovative employee behaviour for intrapreneurship is confirmed in this study, our results also suggest that work context affects intrapreneurship only indirectly. This implies that policies aimed at improving the level of intrapreneurship within organisations through a change in formal and informal work context only have a limited impact, while they may be more successful in stimulating intrapreneurial behaviour amongst employees.

In line with previous research on CE (e.g. Hornsby et al. 2002; Morris et al. 2008), our results highlight that entrepreneurial behaviour within an organisation requires a formal work context that poses little constrains on employees (allows for horizontal 
participation) and provides support for the development innovative projects (resource availability). This result is also in line with intrapreneurship research by Zampetakis et al. (2009), who show that perceived organisational support affects the level of intrapreneurial behaviour by employees. Like the formal work context, the informal work context plays an important role in stimulating intrapreneurial behaviour amongst employees. Research by, e.g., Wakkee et al. (2010) provides evidence that coaching by the direct manager affects intrapreneurial behaviour by employees. Our conceptualisation of social exchange processes as trust between the manager and employee, builds on these results and shows that the nature of the interpersonal relationship can enhance intrapreneurial behaviour. This holds regardless of the learning effects that are associated with coaching and also when controlling for the formal work context in which an employee operates. The absence of a relationship between the different indicators for organisational work context and risk taking implies that employee risk taking is difficult to stimulate with company policies or management interaction.

In contrast to our expectations, no significant negative relationship between formalisation and intrapreneurial behaviour has been found. A closer examination of the relationship between employees that have low and high trust in their manager highlights, however, the complexity of the different relationships. Employees that do not trust their manager display lower levels of innovative workplace behaviour when working in highly formalized organisations. Employees that trust their manager are, on the other hand, not obstructed by high levels of formalization and show even more innovative workplace behaviour. This surprising finding can be explained by the nature of formalization. Rules and formal procedures can be obstructive, but also serve a certain purpose within organisations as they can offer guidance to employees when dealing with uncertain situations. When dealing with a high number of formal procedures, trust in the exchange relationship can be crucial when intrapreneurial actions motivate employees to abandon formal procedures and organisational rules. In these situations, employees must be able to trust their direct supervisor that (s)he provides support in case things go wrong. Our research therefore provides initial support for the proposition of Dess et al (2003) that social exchanges between managers and employees play an important role in the intrapreneurial process and, in a more general sense, reaffirms the key role of managers within CE as suggested by, e.g., Hornsby et al. (2002).

Although the value of risk taking at firm level has been well established (e.g. Rauch et al. 2009), our results raise questions on the value of risk taking for intrapreneurship. Previous studies have not examined the relationship between entrepreneurial behaviour and intrapreneurship and typically used a composite measure of intrapreneurship (e.g., Moriano et al. 2011; Wakkee et al. 2010; Zampetakis et al. 2009). Given the current state of empirical research in this area, our analysis of the individual dimensions of intrapreneurship provides insight into the value of each individual dimension. Although risk taking behaviour may positively co-vary with other dimensions of intrapreneurial behaviour, this does not automatically imply that risk taking leads to actual intrapreneurship. Given that employee initiated projects can be rejected at many different stages, the successful implementation of intrapreneurial projects may require innovative behaviours and personal initiative but not necessarily high levels of employee risk taking. 
Risk taking by employees may therefore be a less relevant dimension for intrapreneurship than previously assumed. This also relates to CE studies, which do not always find a relationship between risk taking and company performance (e.g. Kraus et al. 2012).

\subsection{Limitations and future research}

Of course, this study is subject to certain limitations. First, the study relies on selfreported data. The use of self-reported data is very common in intrapreneurship studies (Axtell et al. 2000; Bosma et al. 2012; Monsen and Boss 2009; Moriano et al. 2011; Wakkee et al. 2010; Zampetakis et al. 2009) and in CE research in general (Rauch et al. 2009). We, however, readily acknowledge that self-reported measures are inferior to objective measures of intrapreneurial behaviour and intrapreneurship, even when applying post-hoc as well as ad-hoc measures to prevent a common method bias.

The verification of the two-step model in this study is limited by the use of cross sectional data. The two-step model of intrapreneurship suggests that employees first display intrapreneurial behaviour before they initiate an intrapreneurial project. In future research, this sequence should ideally be tested with longitudinal data coupled with qualitative studies. The absence of any significant correlations between risk taking and all other variables makes it difficult to compare the model fits of the two-step and the direct model. Although this study indicates that the value of risk taking behaviour for intrapreneurship is, at the very least, questionable, a comparison across all three behavioural dimensions would have added more robustness. The verification of the twostep model is further limited by the removal of the variable for vertical participation due to a lack of discriminatory validity. An interesting avenue for future intrapreneurship studies could therefore be to include more relevant dimensions of an organisational structure in their empirical models. Such research should also address the effect of external factors on intrapreneurial behaviour and intrapreneurship. Research by e.g. Antoncic and Hisrich (2001) has shown that the level of intrapreneurship within a firm is influenced by external factors such as dynamism, rivalry and industry growth. The inclusion of such external factors will provide more advanced insights into the driving forces behind employee intrapreneurial behaviours that go beyond the formal and informal work context of a firm.

The operationalization of the different constructs is another important limitation in this study. Our proxy for intrapreneurship, for instance, does not specify the type of intrapreneurial project that is being realized (product, service, process, etc.), while this could provide important insights in the results of intrapreneurial projects within organisations. Unfortunately, well validated intrapreneurship measurement instruments are scarce. Future studies should therefore focus on the development of measurement scales for both intrapreneurial behaviours as well as intrapreneurship. Another interesting stream of research could focus on the difference between intrapreneurial conditions within SMEs and large firms. Although one would expect that the absence of more complex formal organisational structures and procedures in SMEs would enhance intrapreneurial behaviour and intrapreneurship, our analysis suggest the opposite. More research is therefore needed to describe the specific frame conditions under which intrapreneurship can flourish in different type of organisations. 
The use of social exchange theory is a very promising approach within intrapreneurship research. The operationalization of trust in our study is, however, limited to trust in the manager and does not, for instance, distinguishes between different levels of trust, e.g., in other managers, colleagues, or stakeholders. More research is needed to shed light on the different dimensions of employee behaviour, the skills and the attitudes that are relevant for the intrapreneurial process. Even though we have found only partial support for the mediating role of trust in the direct supervisor, our relative small sample size, in combination with a complex empirical model, results in modest statistical power and therefore an increased chance for type II errors (Lindsay 1993). Moreover, an overall evaluation of the differences between employees that have low and high levels of trust in the direct supervisor was not possible due to the relative small sample size. The results of the moderation analysis should therfore be interpreted with care and call for further research. Finally, we assumed that employee initiated projects contribute to innovation within the organisation and, thereby, enhance both employee and organisational performance. Although theoretical work (Kanter 1988; Pinchot 1986) argues in favour of innovative projects, the specific contribution of employee initiated innovative projects to overall firm performance and to employee performance needs more empirical research.

\section{Acknowledgements}

The authors would like to thank the editors of this special issue, Prof. dr. Jeffery Hornsby, dr. Iñaki Peña and dr. Maribel Guerrero, for inviting us to submit our paper. Many thanks also to two anonymous reviewers for their constructive comments and to Jessica Krom and Heleen van der Meer for their help with the data collection.

\section{Bibliography}

Alexander, J. W., \& Randolph, W. A. (1985). The Fit between Technology and Structure as a Predictor of Performance in Nursing Subunits. The Academy of Management Journal, 28(4), 844-859.

Antoncic, B., \& Hisrich, R. D. (2001). Intrapreneurship: Construct refinement and crosscultural validation. Journal of Business Venturing, 16(5), 495-527.

Arbuckle, J. L. (2007). AMOS 16 user's guide. Chicago SPSS.

Axtell, C. M., Holman, D. J., Unsworth, K. L., Wall, T. D., Waterson, P. E., \& Harrington, E. (2000). Shopfloor innovation: Facilitating the suggestion and implementation of ideas. Journal of Occupational and Organisational Psychology, 73(3), 265-285.

Bijlsma-Frankema, K. (2000). Correlates of trust in a general hospital. In A. Rahim, R. T. Golembiewski, \& K. D. MacKenzie (Eds.), Current Topics in Management (pp. 141-166). Greenwich, CT: JAI Press.

Bijlsma-Frankema, K., de Jong, B., \& van de Bunt, G. (2008). Heed, a missing link between trust, monitoring and performance in knowledge intensive teams. The International Journal of Human Resource Management, 19(1), 19-40.

Bijlsma, K., \& Van de Bunt, G. G. (2003). Antecedents of trust in managers: a "bottom up" approach. Personnel Review, 32(5), 638-664.

Blau, P. M. (1967). Exchange and Power in Social Life. New York, London, Sydney: John Wiley \& Sons Inc. 
Bosma, N., Wennekers, S., \& Amorós, J. E. (2012). GLOBAL ENTREPRENEURSHIP MONITOR 2011 EXTENDED REPORT: Entrepreneurs and Entrepreneurial Employees Across the Globe. (pp. 1-239): Global Entrepreneurship Monitor.

Burgelman, R. A. (1983). A Process Model of Internal Corporate Venturing in the Diversified Major Firm. Administrative Science Quarterly, 28(2), 223-244.

Burns, P. (2008). Corporate Entrepreneurship: Building the Entrepreneurial Organisation (Vol. 2 edn ed). Basingstoke: Palgrave.

Byrne, D. M. (2010). Structural Equation Modeling with AMOS: Basic concepts, applications and programming (Second Edition). New York, London: Routledge.

Carrier, C. (1996). Intrapreneurship in small businesses: an exploratory study. Entrepreneurship Theory and Practice, 21(1), 5-20.

Chisholm, T. A. (1987). Intrapreneurship and bureaucracy. Advanced Management Journal, 52(3), 36-40.

Commission, E. (2003). SME definition: commission recommendation of 06 May 2003. Brussels: EU Commission.

Covin, J. G., Green, K. M., \& Slevin, D. P. (2006). Strategic process effects on the entrepreneurial orientation-sales growth rate relationship. Entrepreneurship: Theory \& Practice, 30(1), 57-81.

Covin, J. G., \& Lumpkin, G. T. (2011). Entrepreneurial Orientation Theory and Research: Reflections on a Needed Construct. Entrepreneurship Theory and Practice, 35(5), 855-872.

Covin, J. G., \& Slevin, D. (1989). Strategic management in small firms in hostile and benign environments. Strategic Management Journal, 10(1), 75-87.

D'Souza, P., \& Mulla, R. (2011). Can an Entrepreneurial Personality Compensate for a Boring Job? : The Influence of Proactive Personality and Job Characteristics on Employee Engagement Levels. Journal of Entrepreneurship, 20(2), 207-226.

Day, D. L. (1994). Raising Radicals: Different Processes for Championing Innovative Corporate Ventures. Organisation Science, 5(2), 148-172.

De Jong, J. P. J., \& Den Hartog, D. N. (2005). Determinanten van Innovatief Gedrag: Een Onderzoek onder Kenniswerkers in het MKB (Determinants of Innovative Behavior: An Investigation among Knowledge workers in SMEs). Gedrag \& Organisatie, 18, 235-259.

De Jong, J. P. J., \& Den Hartog, D. N. (2010). Measuring Innovative Work Behaviour. Creativity and Innovation Management, 19(1), 23-36.

De Jong, J. P. J., Parker, S. K., Wennekers, S., \& Wu, C. (2011). Corporate Entrepreneurship at the Individual Level: Measurement and Determinants (H201108). Zoetemeer: EIM Research Reports.

De Vaus, D. A. (2002). Analysing Social Science Data: 50 Key Problems in Data Analysis. London, Thousand Oaks, New Deli: Sage Publications.

Dess, G. G., Ireland, R. D., Zahra, S. A., Floyd, S. W., Janney, J. J., \& Lane, P. J. (2003). Emerging Issues in Corporate Entrepreneurship. Journal of Management, 29(3), 351-378.

Dillman, D. A. (1978). Mail and telephone surves: the total design method. New York: John Wiley \& Sons.

Emerson, R. M. (1976). Social Exchange Theory. Annual Review of Sociology, 2, 335362. 
Folger, R. (1987). Reformulating the Preconditions of Resentment: A Referent Cognition Model. In J. C. Masters, \& W. P. Smith (Eds.), Social Comparison, Social Justice, and Relative Deprivation: Theoretical, Empirical and Policy Perspectives. Hillsdale, NJ, London: Lawrence Erlbaum Associates Publischers.

Folger, R. (1993). Justice, motivation, and performance beyond role requirements. Employee Responsibilities and Rights Journal, 6(3), 239-248.

Frese, M., Fay, D., Hilburger, T., Leng, K., \& Tag, A. (1997). The concept of personal initiative: Operationalization, reliability and validity in two German samples. Journal of Occupational and Organisational Psychology, 70(2), 139-161.

Frese, M., Kring, W., Soose, A., \& Zempel, J. (1996). Personal Initiative at Work: Differences between East and West Germany. The Academy of Management Journal, 39(1), 37-63.

Gambetta, D. G. (1988). Can we Trust Trust? In D. G. Gambetta (Ed.), Trust: Making and Breaking Cooperative Relations (pp. 213-237). New York, New York: Basil Blackwell.

Gertz, D., \& Baptista, J. (1996). Grow to be Great. New York, New York: Free Press.

Ginsberg, A., \& Hay, M. (1994). Confronting the challenges of corporate entrepreneurship: Guidelines for venture managers. European Management Journal, 12(4), 382-389.

Goodale, J. C., Kuratko, D. F., Hornsby, J. S., \& Covin, J. G. (2011). Operations management and corporate entrepreneurship: The moderating effect of operations control on the antecedents of corporate entrepreneurial activity in relation to innovation performance. Journal of Operations Management, 29(1-2), 116-127.

Hair, J. F., Black, B., Babin, B., \& Anderson, R. E. (2007). Multivariate Data Analysis: seventh edition (6th edn ed.). Englewood Cliffs, New Jersey: Prentice Hall.

Hayton, J. C. (2005). Promoting corporate entrepreneurship through human resource management practices: a review of empirical research. Human Resource Management Review, 15(1), 21-41.

Hayton, J. C., \& Kelley, D. J. (2006). A competency-based framework for promoting corporate entrepreneurship. Human Resource Management, 45(3), 407-427.

Hisrich, R. (1990). Entrepreneurship/Intrapreneurship. American Psychologist, 45(2), 209-222.

Holt, D. T., Rutherford, M. W., \& Clohessy, G. R. (2007). Corporate Entrepreneurship: An Empirical Look at Individual Characteristics, Context, and Process. Journal of Leadership \& Organisational Studies, 13(4), 40-54.

Hornsby, J. S., Kuratko, D. F., \& Montagno, R. V. (1999). Perception of internal factors for corporate entrepreneurship: A comparison of Canadian and U.S. managers. Entrepreneurship Theory and Practice, 24(2), 9-24.

Hornsby, J. S., Kuratko, D. F., Shepherd, D. A., \& Bott, J. P. (2009). Managers' corporate entrepreneurial actions: Examining perception and position. Journal of Business Venturing, 24(3), 236-247.

Hornsby, J. S., Kuratko, D. F., \& Zahra, S. A. (2002). Middle managers perception of the internal environment for corporate entrepreneurship: assessing a measurement scale. Journal of Business Venturing, 17(3), 253-274. 
Hornsby, J. S., Naffziger, D. W., Kuratko, D. F., \& Montagno, R. V. (1993). An Interactive Model of the Corporate Entrepreneurship Process. Entrepreneurship: Theory \& Practice, 17(2), 29-37.

Ireland, R. D., Covin, J. G., \& Kuratko, D. F. (2009). Conceptualizing Corporate Entrepreneurship Strategy. Entrepreneurship Theory and Practice, 33(1), 19-46.

Kanter, R. M. (1985). Supporting innovation and venture development in established companies. Journal of Business Venturing, 1(1), 47-61.

Kanter, R. M. (1988). When a thousand flowers bloom: structural, collective and social conditions for innovation in organisation. Research in Organisational Behaviour, $10,169-211$.

Kemelgor, B. H. (2002). A comparative analysis of corporate entrepreneurial orientation between selected firms in the Netherlands and the USA. Entrepreneurship and Regional Development, 14, 67-87.

Kirby, D. (2006). Creating Entrepreneurial Universities in the UK: Applying Entrepreneurship Theory to Practice. The Journal of Technology Transfer, 31(5), 599-603.

Klepper, S. (2001). Employee Startups in High Tech Industries. Industrial and Corporate Change, 10(3), 639-674.

Knight, R. M. (1987). Corporate innovation and entrepreneurship: A Canadian study. Journal of Product Innovation Management, 4(4), 284-297.

Kraus, S., Rigtering, J. P. C., Hughes, M., \& Hosman, V. (2012). Entrepreneurial orientation and the business performance of SMEs: a quantitative study from the Netherlands. Review of Managerial Science, 6(2), 161-182.

Kuratko, D. F., \& Goldsby, M. G. (2004). Corporate Entrepreneurs or Rogue Middle Managers? A Framework for Ethical Corporate Entrepreneurship. Journal of Business Ethics, 55(1), 13-30.

Kuratko, D. F., Ireland, R. D., Covin, J. G., \& Hornsby, J. S. (2005). A Model of MiddleLevel Managers' Entrepreneurial Behavior. Entrepreneurship Theory \& Practice, 29(6), 699-716.

Leifer, R., \& Huber, G. P. (1977). Relations Among Perceived Environmental Uncertainty, Organisation Structure, and Boundary-Spanning Behavior. Administrative Science Quarterly, 22(2), 235-247.

Lindsay, R. M. (1993). Incorporating statistical power into the test of signifcance procedure: A methodological and emprical inquiry. Behavioral Research in Accounting, 5, 211-236.

Lumpkin, G. T., \& Dess, G. G. (1996). Clarifying the entrepreneurial orientation construct and linking it to performance. Academy of Management Review, 21(1), 135-172.

Marvel, M. R., Griffin, A., Hebda, J., \& Vojak, B. (2007). Examining the Technical Corporate Entrepreneurs' Motivation: Voices from the Field. Entrepreneurship Theory and Practice, 31(5), 753-768.

Menzel, H. C., Aaltio, I., \& Ulijn, J. M. (2007). On the way to creativity: Engineers as intrapreneurs in organisations. Technovation, 27(12), 732-743.

Miller, D. (1983). The correlates of entrepreneurship in three types of firms. Management Science, 29(7), 770-791. 
Mintzberg, H. (1993). Structure in fives: Designing effective organisations. Englewood Cliffs, NJ, US: Prentice-Hall, Inc. .

Möllering, G. (2005). Retional, Institutional and Active Trust: Just Do It!? In K. M. Bijlsma-Frankema, \& R. J. A. Klein Woolthuis (Eds.), Trust under Pressure: Emperical Investigations of Trust and Trust Building in Uncertain Circumstances (pp. 17-36). Cheltenham: Edward Elgar.

Monsen, E., \& Boss, W. (2009). The Impact of Strategic Entrepreneurship inside the Organisation: Examining Job Stress and Employee Retention. Entrepreneurship: Theory \& Practice, 33(1), 71-104.

Moriano, J., Molero, F., Topa, G., \& Lévy Mangin, J.-P. (2011). The influence of transformational leadership and organisational identification on intrapreneurship. International Entrepreneurship and Management Journal, 1-17.

Morris, M. H., Kuratko, D. F., \& Covin, J. G. (2008). Corporate Entrepreneurship \& Innovation (2nd ed.). Mason, OH, USA: Thomson Higher Education.

Parker, J. D. A., Taylor, G. J., \& Bagby, R. M. (2003). The 20-Item Toronto Alexithymia Scale: III. Reliability and factorial validity in a community population. Journal of Psychosomatic Research, 55(3), 269-275.

Parker, S. K., \& Collins, C. G. (2010). Taking Stock: Integrating and Differentiating Multiple Proactive Behaviors. Journal of Management, 36(3), 633-662.

Pinchot, G. (1986). Intrapreneuring. Why You Don't have to Leave the Corporation to Become an Entrepreneur. New York: Perennial Library.

Podsakoff, P. M., MacKenzie, S. B., Lee, J.-Y., \& Podsakoff, N. P. (2003). Common method biases in behavioral research: A critical review of the literature and recommended remedies. Journal of Applied Psychology, 88(5), 879-903.

Podsakoff, P. M., \& Organ, D. W. (1986). Self-reports in organisational research: Problems and prospects. Journal of Management, 12(4), 531-544.

Rauch, A., Wiklund, J., Lumpkin, G. T., \& Frese, M. (2009). Entrepreneurial Orientation and Business Performance: An Assessment of Past Research and Suggestions for the Future. Entrepreneurship Theory and Practice, 33, 761-787.

Rigdon, E. E. (1996). CFI versus RMSEA: A comparison of two fit indexes for structural equation modeling. Structural Equation Modeling: A Multidisciplinary Journal, 3(4), 369-379.

Rousseau, D. M. (1989). Psychological and implied contracts in organisations. Employee Responsibilities and Rights Journal, 2(2), 121-139.

Rutherford, M. W., \& Holt, D. T. (2007). Corporate entrepreneurship: An empirical look at the innovativeness dimension and its antecedents. Journal of Organisational Change Management, 20(3), 429-446.

Sharma, P., \& Chrisman, J. J. (1999). Toward a reconciliation of the definitional issues in the field of corporate entrepreneurship. Entrepreneurship Theory \& Practice, 23(3), 11-27.

Stam, E., Bosma, N., Van Witteloostuijn, A., De Jong, J., Bogaert, S., Edwards, N., et al. (2012). Ambitious Entrepreneurship: A Review of the Academic Literature and Directions for Public Policy. (pp. 1-162). Den Haag: Advisory Council for Science and Technology Policy.

Stevenson, H. H., \& Jarillo, J. C. (1990). A paradigm of entrepreneurship: entrepreneurial management. Strategic Management Journal, 11(4), 17-27. 
Sun, L.-Y., \& Pan, W. (2009). Market Orientation, Intrapreneurship Behavior, and Organisational Performance: Test of a Structural Contingency Model. Journal of Leadership \& Organisational Studies.

Vesper, K. H. (1984). Three faces of corporate entrepreneurship: A pilot study, In: J. A, Hornaday, F. Tarpley jr. \& J.A. Timmons (ed.) Frontiers of Entrepreneurship Research. Wellesley, Massachusetts: Babson College.

Wakkee, I., Elfring, T., \& Monaghan, S. (2010). Creating entrepreneurial employees in traditional service sectors. International Entrepreneurship and Management Journal, 6(1), 1-21.

Wales, W., Monsen, E., \& McKelvie, A. (2011). The Organisational Pervasiveness of Entrepreneurial Orientation. Entrepreneurship Theory and Practice, 35(5), 895923.

West, M. A., Farr, J. L. (1990) Innovation and Creativity at Work: Psychological and organisational strategies. London, UK, John Wiley \& Sons.

Wiklund, J., \& Shepherd, D. A. (2005). Entrepreneurial Orientation and Small Business Performance: A Configuration Approach. Journal of Business Venturing, 20(1), 71-91.

Yang, C.-W. (2008). The Relationships Among Leadership Styles, Entrepreneurial Orientation, and Business Performance. Managing Global Transitions, 6(3), 257275.

Zahra, S. A. (1991). Predictors and financial outcomes of corporate entrepreneurship: An exploratory study. Journal of Business Venturing, 6(4), 259-286.

Zahra, S. A. (1995). Corporate entrepreneurship and financial performance: The case of management leveraged buyouts. Journal of Business Venturing, 10(3), 225-247.

Zahra, S. A., \& Covin, J. G. (1995). Contextual influences on the corporate entrepreneurship-performance relationship: a longitudinal analysis. Journal of Business Venturing, 10, 43-58.

Zampetakis, L. A., Beldekos, P., \& Moustakis, V. S. (2009). "Day-to-day" entrepreneurship within organisations: The role of trait Emotional Intelligence and Perceived Organisational Support. European Management Journal, 27(3), 165175. 


\section{Tables and Figures}

Figure 1: Theoretical model and hypotheses

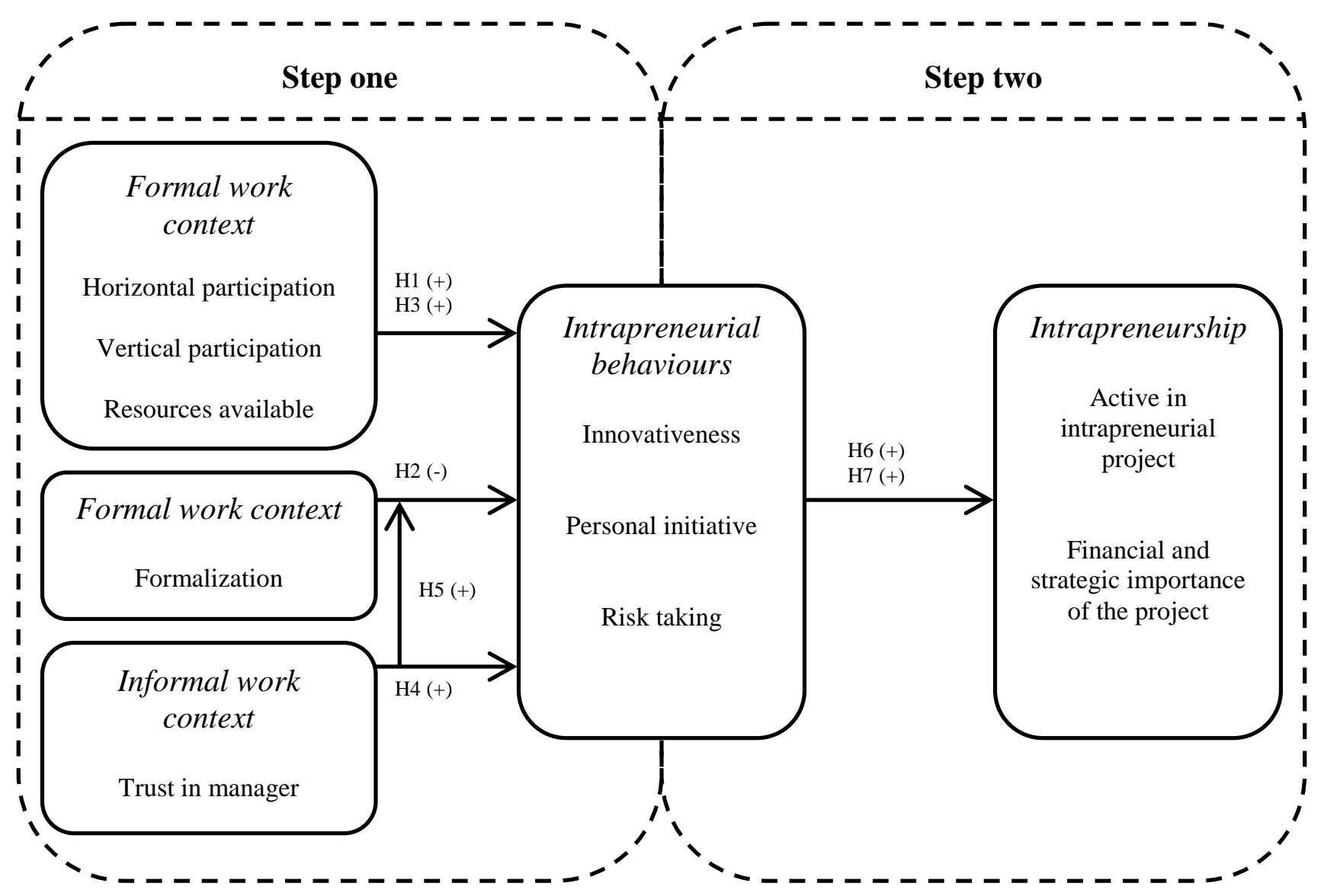

Note: The hypothesized relationships, together with the expected direction

( + or - ) of the relationship, are included in the model. 
Table 1

Overview sample statistics

\begin{tabular}{lc}
\hline & \\
\hline Total number of returned questionnaires & 176 \\
Response rate & $36.97 \%$ \\
Percentage males & $40.3 \%$ \\
Percentage females & $59.7 \%$ \\
Average age & 42.51 years \\
Percentage highly educated employees (BSc. or higher) & $67,4 \%$ \\
Percentage employees with lower or medium education (no BSc.) & $32,6 \%$ \\
Percentage team leaders/operational managers & $14,3 \%$ \\
Percentage employees & $85,7 \%$ \\
\hline
\end{tabular}


Table 2

Means, S.D., correlations and reliability for quantitative variables

\begin{tabular}{|c|c|c|c|c|c|c|c|c|c|c|c|c|c|c|c|c|c|c|}
\hline Variable & $\mathbf{N}$ & $\mathbf{M}$ & SD & 1 & 2 & 3 & 4 & 5 & 6 & 7 & 8 & 9 & 10 & 11 & 12 & 13 & 14 & 15 \\
\hline 1. Male & 176 & 0.40 & 0.49 & $(-)$ & & & & & & & & & & & & & & \\
\hline 2. Age & 170 & 42.51 & 11.96 & -.07 & $(-)$ & & & & & & & & & & & & & \\
\hline 3. Team leader & 175 & 0.14 & 0.35 & $.23 * *$ & .13 & $(-)$ & & & & & & & & & & & & \\
\hline 4. SME & 176 & 0.37 & 0.48 & -.14 & .14 & -.06 & $(-)$ & & & & & & & & & & & \\
\hline 5. Non-profit & 176 & 0.69 & 0.46 & -.13 & $.16^{*}$ & -.05 & $-.87 * *$ & $(-)$ & & & & & & & & & & \\
\hline 6. Trust in manager & 163 & 5.37 & 1.31 & .10 & -.12 & $.20 * *$ & .14 & -.11 & $(.90)$ & & & & & & & & & \\
\hline 7. Horizontal Participation & 173 & 4.72 & 1.00 & -.02 & -.12 & $.21 * *$ & .14 & -.13 & .00 & $(.67)$ & & & & & & & & \\
\hline 8. Formalization & 174 & 4.27 & 1.26 & .03 & $.23 * *$ & .02 & $-.22 * *$ & $.25^{* *}$ & .00 & .00 & $(.72)$ & & & & & & & \\
\hline 9. Resource availability & 170 & 4.57 & 1.38 & .08 & -.04 & -.05 & $.27 * *$ & $-.29 * *$ & .00 & .00 & .00 & $(.90)$ & & & & & & \\
\hline 10. Innovative workplace behavior & 160 & 4.90 & 0.87 & .12 & .02 & $.21 * *$ & $-.18 *$ & $.20 *$ & $.18 *$ & $.25 * *$ & $.16 \dagger$ & .13 & $(.88)$ & & & & & \\
\hline 11. Personal Initiative & 162 & 5.16 & 0.84 & -.05 & -.10 & .12 & -.08 & .04 & $.25 * *$ & $.19 *$ & .12 & .12 & $.67 * *$ & $(.84)$ & & & & \\
\hline 12. Risk taking & 165 & 2.94 & 1.15 & $.18^{*}$ & -.11 & .13 & -.02 & -.06 & -.08 & .10 & -.03 & .07 & .08 & $.16^{*}$ & $(.68)$ & & & \\
\hline 13. Intrapreneurship & 152 & 0.54 & 0.50 & .07 & .01 & .14 & $-.24 * *$ & $.17 *$ & .11 & .13 & -.06 & -.11 & $.29 * *$ & $.33 * *$ & -.11 & $(-)$ & & \\
\hline 14. Financial importance & 122 & 2.89 & 1.11 & $.24 * *$ & .10 & $.24 * *$ & .13 & -.06 & .02 & .05 & -.13 & .00 & $.28 * *$ & .15 & $.16 \dagger$ & .01 & $(-)$ & \\
\hline 15. Strategic importance & 123 & 3.40 & 1.01 & .11 & .03 & $.24 * *$ & .03 & -.03 & .15 & .02 & -.07 & -.02 & $.35^{* *}$ & $.29 * *$ & .13 & .09 & $.59 * *$ & $(-)$ \\
\hline
\end{tabular}

Notes: In the diagonal axis the reliabilities (Cronbach's alpha) are shown. For one-item measures Cronbach's alphas cannot be computed, these are labeled (-).

$\dagger, *, * *$ : denote, levels of statistical significance at $\mathrm{P}=<.10, .05, .01$, respectively. 
Table 3

Validation of the two step model of intrapreneurship

\begin{tabular}{|c|c|c|c|}
\hline & \multicolumn{3}{|c|}{ Different models } \\
\hline & $\begin{array}{l}\text { Innovative } \\
\text { workplace } \\
\text { behaviours }\end{array}$ & $\begin{array}{l}\text { Personal } \\
\text { initiative }\end{array}$ & $\begin{array}{l}\text { Risk taking } \\
\text { behaviours }\end{array}$ \\
\hline \multicolumn{4}{|l|}{ Comparison $\chi^{2}$} \\
\hline Two step model & $6.561(4), p=>.05$ & $\begin{array}{c}6.995(4), p=> \\
.05\end{array}$ & $6.879(4), p=>.05$ \\
\hline Direct model & $\begin{array}{c}13.050(1), p=< \\
.000\end{array}$ & $\begin{array}{c}16.797(1), p=< \\
.000\end{array}$ & $1.701(1), p=>.05$ \\
\hline \multicolumn{4}{|l|}{$\begin{array}{l}\text { Comparison } \\
\text { RMSEA }\end{array}$} \\
\hline Two step model & .060 & .065 & .064 \\
\hline Direct model & .262 & .300 & .063 \\
\hline
\end{tabular}


Table 4

Structural relationships within the model

\begin{tabular}{|c|c|c|c|}
\hline \multirow[t]{2}{*}{ Variable } & \multicolumn{3}{|c|}{ Respective dimension of intrapreneurial behavior } \\
\hline & $\begin{array}{l}\text { Innovative } \\
\text { workplace } \\
\text { behaviors }\end{array}$ & $\begin{array}{l}\text { Personal } \\
\text { initiative }\end{array}$ & $\begin{array}{l}\text { Risk taking } \\
\text { behaviours }\end{array}$ \\
\hline & $\beta$ & B & B \\
\hline Male & .10 & -.08 & $.18^{*}$ \\
\hline Age & .01 & -.08 & $-.14 \dagger$ \\
\hline Team leader & $.14 \dagger$ & .09 & .13 \\
\hline SME & -.15 & -.22 & $-.29 \dagger$ \\
\hline Non-profit & .17 & -.10 & $-.25 \dagger$ \\
\hline Trust & $.16^{*}$ & $.24 * *$ & -.12 \\
\hline Horizontal participation & $.27 * *$ & $.19 *$ & .07 \\
\hline Formalization & .08 & .11 & -.01 \\
\hline Resource availability & $.21 * *$ & $.16^{*}$ & .07 \\
\hline \multirow[t]{3}{*}{ Variable } & \multicolumn{3}{|c|}{ Effects on intrapreneurship } \\
\hline & Intrapreneurship & $\begin{array}{c}\text { Financial } \\
\text { importance of } \\
\text { intrapreneurial } \\
\text { project }\end{array}$ & $\begin{array}{c}\text { Strategic } \\
\text { importance of } \\
\text { intrapreneurial } \\
\text { project }\end{array}$ \\
\hline & $\begin{array}{c}95 \% \text { confidence } \\
\text { interval } \beta\end{array}$ & B & B \\
\hline SME & -.34 to -.32 & $.31 \dagger$ & .06 \\
\hline Non-profit & -.18 to -.16 & .15 & -.04 \\
\hline $\begin{array}{l}\text { Innovative workplace } \\
\text { behaviors }\end{array}$ & .16 to .17 & $.36^{*}$ & $.42 * *$ \\
\hline $\begin{array}{l}\text { Personal } \\
\text { initiative }\end{array}$ & .18 to .19 & $.20 *$ & $.35 * *$ \\
\hline $\begin{array}{l}\text { Risk taking } \\
\text { behaviours }\end{array}$ & -.06 to -.05 & $.17 \dagger$ & .13 \\
\hline
\end{tabular}

Notes: 1 . In order to reduce model complexity, only the control variables that are significantly related to intrapreneurship have been included in step two of the model. 2. Model fit for innovative workplace behaviours model, personal initiative model and risk taking model, respectively: $\chi^{2}=8.579(7), \mathrm{p}=>.05$, RMSEA .036; $\chi^{2}=10.935(7), \mathrm{p}=>.05$, RMSEA .057; $\chi^{2}=14.666(7), \mathrm{p}=<.05$, RMSEA .079.

$\dagger, *, * *$ : denote, levels of statistical significance at $\mathrm{P}=<.10, .05, .01$, respectively. 
Figure 2:

MCMC comparison first and last thirds of accumulated samples innovative workplace behaviours - intrapreneurship

Direct model

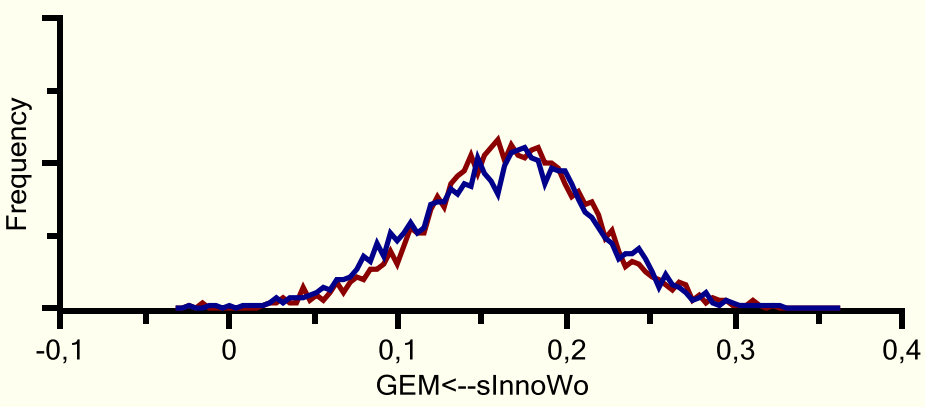

Figure 3:

MCMC comparison first and last thirds of accumulated samples personal initiative intrapreneurship

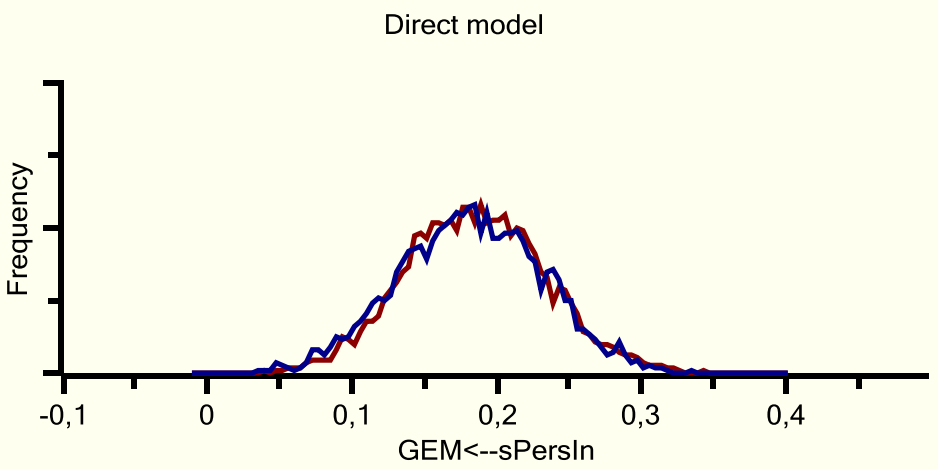

Figure 4:

MCMC comparison first and last thirds of accumulated samples risk taking behaviours intrapreneurship

Direct model

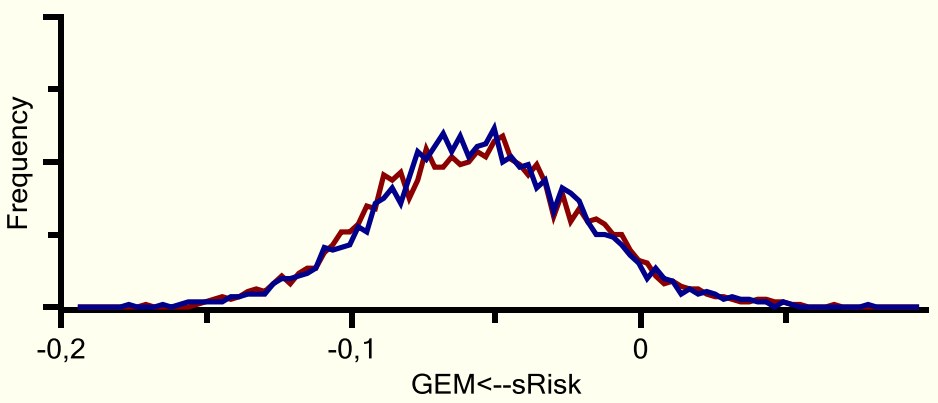




\section{Table 5}

Differences between high and low trust in manager

\begin{tabular}{lcccccc}
\hline Variable & \multicolumn{3}{c}{ Respective dimension of intrapreneurial behavior } \\
\hline & \multicolumn{2}{c}{$\begin{array}{l}\text { Innovative } \\
\text { workplace } \\
\text { behaviors }\end{array}$} & $\begin{array}{c}\text { Personal } \\
\text { initiative }\end{array}$ & $\begin{array}{c}\text { Risk taking } \\
\text { behaviours }\end{array}$ \\
& $\begin{array}{c}\beta \text { low } \\
\text { trust }\end{array}$ & $\begin{array}{c}\beta \text { high } \\
\text { trust }\end{array}$ & $\begin{array}{c}\beta \text { low } \\
\text { trust }\end{array}$ & $\begin{array}{c}\beta \text { high } \\
\text { trust }\end{array}$ & $\begin{array}{c}\beta \text { low } \\
\text { trust }\end{array}$ & $\begin{array}{c}\beta \text { high } \\
\text { trust }\end{array}$ \\
\hline Male & .00 & $.34^{* *}$ & -.06 & -.01 & .11 & $.23 \dagger$ \\
Age & .07 & -.06 & -.11 & -.03 & -.16 & .05 \\
Team leader & $.20 \dagger$ & .09 & .13 & -.01 & $.34^{* *}$ & .01 \\
SME & -.08 & $-.45^{*}$ & -.17 & -.35 & -.42 & -.22 \\
Non-profit & .14 & .07 & -.06 & -.18 & -.22 & -.36 \\
Trust & .05 & .25 & .04 & $.20 \dagger$ & -.02 & -.12 \\
Horizontal participation & $.26^{*}$ & $.33^{* *}$ & $.24 *$ & .18 & .12 & -.01 \\
Formalization & -.12 & $.25^{* *}$ & -.04 & $.23 \dagger$ & -.06 & .01 \\
Resource availability & $.36^{*}$ & $.21^{*}$ & $.27^{*}$ & .12 & .17 & -.08 \\
& & & & & & \\
\hline
\end{tabular}

Note: Model fit for innovative workplace behaviours model, personal initiative model and risk taking model, respectively: $\chi^{2}=9.769(14), \mathrm{p}=>.05$, RMSEA .000; $\chi^{2}=13.776(14), p=>.05$, RMSEA .000; $\chi^{2}=17.168(14), p=>.05$, RMSEA .038 .

$\dagger, *, * *$ : denote, levels of statistical significance at $\mathrm{P}=<.10, .05, .01$, respectively. 